\title{
Conserving idealized landscapes: past history, public perception and future management in the New Forest (UK)
}

\author{
Michael J. Grant · Mary E. Edwards
}

Received: 24 May 2006/ Accepted: 22 November 2006

(C) Springer Verlag 2007

\begin{abstract}
The New Forest is one of the most visited regions of Britain. It has recently been designated a National Park in recognition of its unique wood pasture ecosystems, a traditional land-use system, its magnificent scenery and recreational potential, and its biodiversity importance. The Forest's highly prized Ancient and Ornamental (A\&O) woodlands are a result of complex interactions among human activities of several kinds and the ecology of the dominant species-beech and oak-under the climate conditions of the last one to two millennia. Major changes in management practices over the 20th century, combined with the historical imprint of previous centuries of use, have set the $\mathrm{A} \& \mathrm{O}$ woodlands on a trajectory that means their nature and appearance will inevitably change over the coming decades. When the potential stresses that will be imposed by 21 st century climate change are also considered, it will be challenging to find a management strategy to maintain $\mathrm{A} \& \mathrm{O}$ woodlands in their present form. Beech, which owes its current dominance largely to human disturbances of the woodland ecosystem, will be particularly stressed under future conditions. Future conservation policies, and hence management strategies, must be flexible as to the species composition and structure of future wood-
\end{abstract}

Communicated by M.-J. Gaillard.

\section{J. Grant ( $\square)$}

Centre for Earth and Environmental Science Research,

School of Earth Sciences and Geography,

Kingston University, Penrhyn Road,

Kingston upon Thames, Surrey KT1 2EE, UK

e-mail: M.Grant@Kingston.ac.uk

\section{E. Edwards}

School of Geography, University of Southampton, Highfield, Southampton, Hampshire SO17 1BJ, UK

e-mail: M.E.Edwards@ soton.ac.uk lands. However, the wide range of users and their different values add further complexity to forest management, and managers must also focus on issues of public perception. For example visitors idealize current landscapes, and this exerts a pressure to maintain the status quo as far as appearance is concerned that will be hard to achieve in practice. Management strategies will be greatly constrained unless conflicts about values and uses are resolved.

Keywords New Forest · Wood pasture .

Nature conservation - Fagus . Forest management

\section{Introduction}

The term 'landscape' is commonly used in relation to conservation and land management in Britain, although the concept is difficult to define and its meaning is contested by scholars (e.g. Jones 1991). In its original form the term means 'land shaped by the people' and includes a notion of territory, as a human imprint on the land helps to define a place (Olwig 1996, 2000). Today the concept also applies to areas that lack a human imprint, but in Europe most landscapes do indeed have cultural origins, even when they are commonly viewed as 'natural'. It is often via the appreciation of landscape, in its meaning of 'scene' or 'surroundings', that people experience the species, habitats and ecosystems that are the focus of the conservation biologist, and both the appearance of the landscape and its species complement are central to management goals. This is certainly the case in England's New Forest (Fig. 1), a largely unenclosed tract of forest (meaning land not subdivided under the parliamentary Enclosure Acts of 1698 and 1808), heath and grazed lawns that is still subject to a medieval system of customary common grazing rights 
Fig. 1 Map showing the location of the New Forest and sites referred to within it

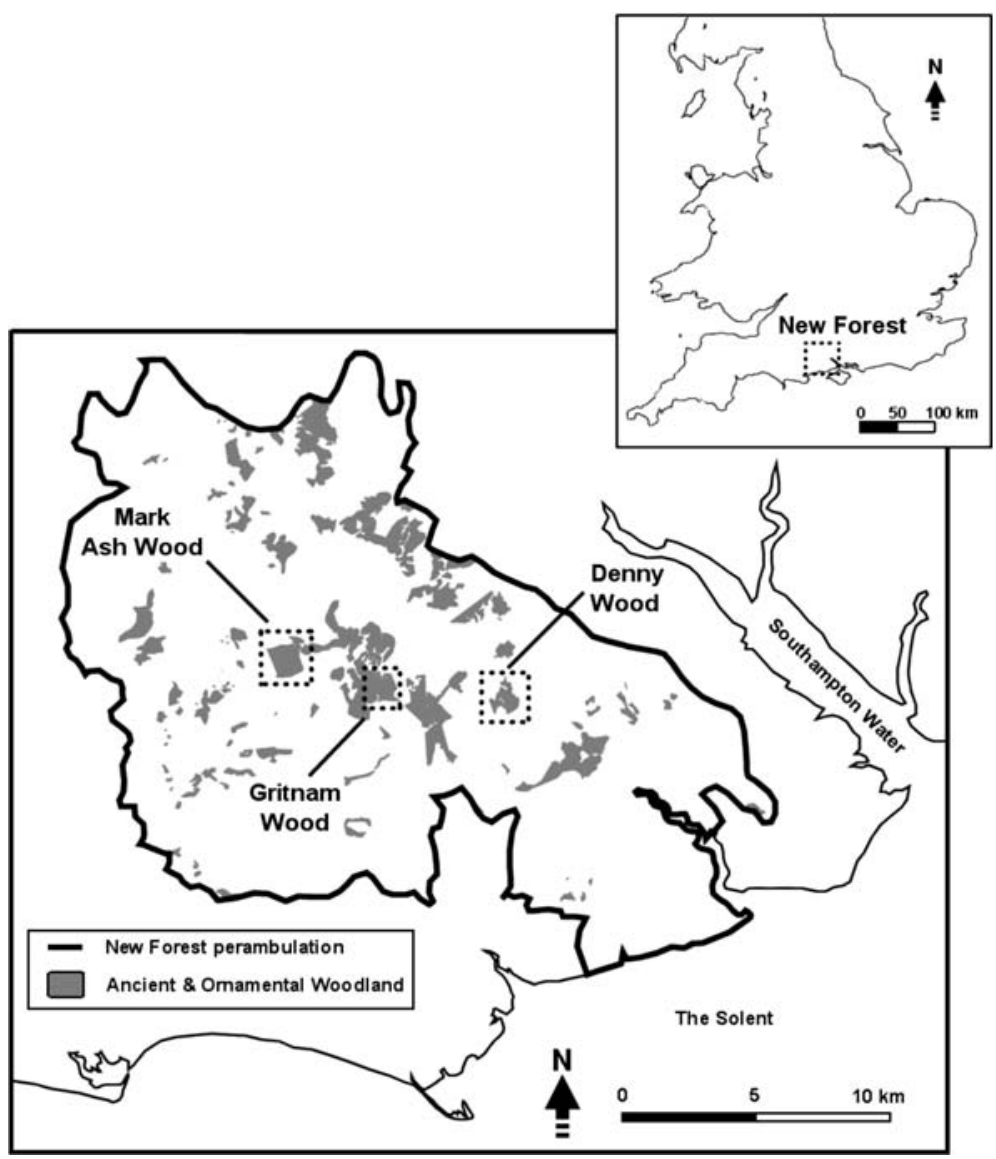

(while also being under the management of a number of government agencies). The forest has long been a favourite of visitors from outside the region, and in 2005 it received National Park status in recognition of its visually unique landscapes, recreation value and biodiversity importance [New Forest National Park (Designation) Order 2005].

While local inhabitants whose activities form and maintain landscapes may still live in an area and often have a strong local sense of place, they have become increasingly marginalized through the 20th century. In many regions, the changing economy of land use has been a major influence. In predominantly agricultural areas, mechanisation and intensification after World War Two and changes in farming subsidies have led to a gradual depopulation of rural areas, and often to the simplification of the rural landscape structure. In the New Forest, however, the long tradition of stock grazing continues and there is little other agriculture. Some land is under forestry management and much of the rest is managed for amenity purposes. The New Forest (even prior to becoming a National Park) has long been highly valued as a recreational area, and it has over 20 million visitors each year (Forestry Commission 2004). Thus, amenity, aesthetics and local economic uses such as grazing and forestry are all of importance to one or more constituencies. However, the balance among the different user groups in the Forest is gradually changing. With the increasing importance of the opinions and perceptions expressed by many visitors and a growing number of second-home owners introducing their expectations of what the area should be like, long-term residents and commoners (those with customary grazing rights) increasingly feel marginalized.

Biodiversity conservation (UNEP 1992) is also of increasing importance. In the New Forest this interest is represented by various conservation authorities and nongovernmental organizations. Under the influence of the US conservation movement, the wilderness/naturalness principle has tended to govern biological conservation goals (Lowenthal 1999), and there is often a focus on areas that are 'least disturbed' by human action. However, in Europe, even areas thought of as barely influenced by human action are increasingly being shown, often by palaeoecological and archaeological studies, to have been affected by past human uses. Thus to the 'natural' environmental determinants of the appearance of landscape and composition of the biota are added current human use and past use. In planning for the future conservation managers have to consider, along with many other issues, the ecological trajectory imparted to the ecosystem by past and present use (Edwards 2005) (Fig. 2). 
The New Forest, then, presents a classic challenge for multiple-use management. Land managers are facing an almost overwhelming multiplicity of pressures: the policy directives and economic pressures that are strong drivers of land use, the requirements of a broad constituency of users whose desires for the future of the New Forest vary, and ecological constraints upon the distribution, growth and regeneration/reproduction of constituent species (Fig. 3). Sometimes goals converge, but often they are radically different, in which case conflicts may arise. Sometimes they are in line with economic forces, but often they are not, which adds extra challenges to planning for the future. In this paper we assess some of these challenges to conservation management, particularly in light of information on past use and the palaeoecological record of key species, and we suggest that the landscapes of the New Forest will inevitably change in the future. Our focus is the 'Ancient and Ornamental (A\&O) woodland' that epitomizes New Forest landscapes for many people and is also of high biodiversity value. We conclude that an important extra aspect of management of the New Forest will be that of users' perceptions, as long-held assumptions about the nature of the Forest—its 'idealized landscapes'—will prove untenable in decades to come.

\section{Current legislation and protection}

The New Forest pasture woodlands cover some 4,430 ha (excluding riverine and bog woodland). They comprise some 3,100 ha of old growth woodland, often termed A\&O woodland, and 1,330 ha of more recent secondary forest expansion (Fig. 1). The A\&O woodlands are one of the most celebrated landscapes of the New Forest and are regarded as some of the finest examples of lowland wood pasture in Europe (Peterken et al. 1999; Tubbs 2001). The term $\mathrm{A} \& \mathrm{O}$ is open to many interpretations, but is most often applied to woods that are known to date from before the 17th century A.D. (Peterken et al. 1999).

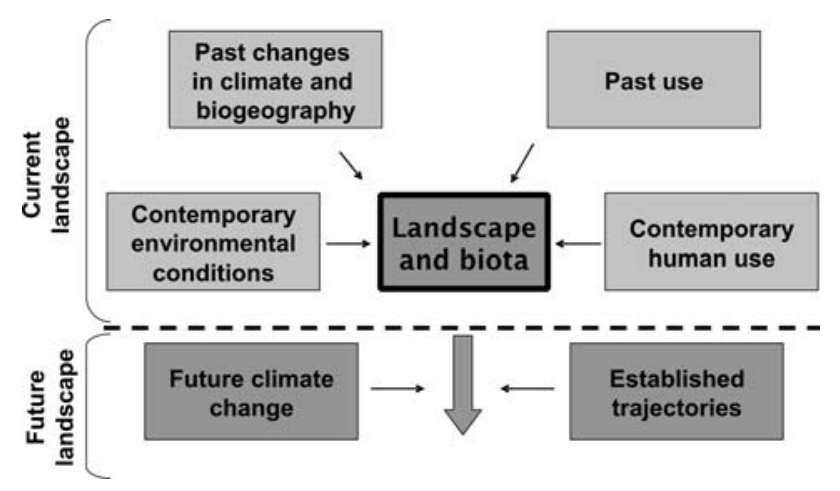

Fig. 2 Determinants of current landscape and biota

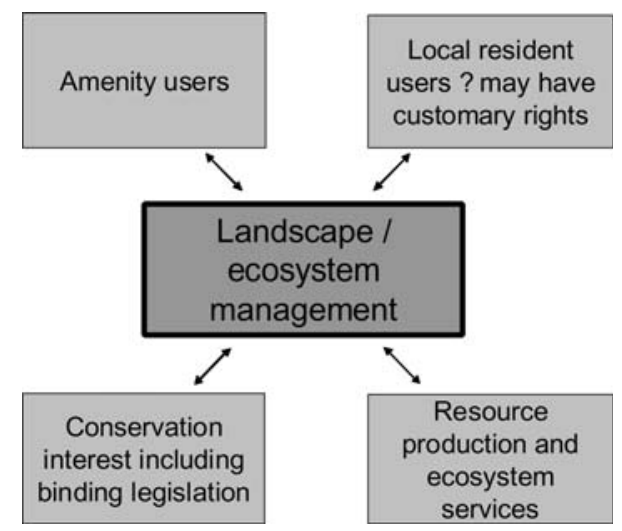

Fig. 3 Multiple-use management challenges in the New Forest

Grazing has led to a sparse but diverse ground flora (e.g. Chatters 1995; Mountford et al. 1999; Peterken et al. 1999; Tubbs 2001). The older trees support the richest lichen flora in lowland Europe (some 350 species; Rose and James 1974; New Forest Committee 2003) and a large number of invertebrate species associated with standing dead wood habitats. These pasture woodlands are also among the richest sites for mosses and liverworts in lowland Britain and host an abundance of fungi, with many rare and notable species (Peterken et al. 1996, 1999; New Forest Committee 2003; JNCC 2002).

A large proportion of A\&O woodland is covered by conservation designations. About 2,250 ha fall within habitats of the EEC Habitats Directive (HD) Annex 1 habitats (EEC 1992); Atlantic acidophilous beech (2,000 ha; type 9120; NVC types W14 and W15), Old acidophilous oak (120 ha; type 9190; NVC type W16 and some W10) and Asperulo-fagetum beech woods (400 ha; type 9130; NVC type W12). The remainder consists of mesotrophic, herbrich oak woodland, which has no HD equivalent. A\&O woodlands are also designated in the UK as Sites of Special Scientific Interest (SSSI) under the Wildlife and Countryside Act 1981, a Special Protection Area for birds (SPA) under the Ramsar Convention and a Special Area of Conservation (SAC) under the European Union's HD.

The large areas of protected forest are clearly of the highest priority for nature conservation. However, in many cases, past management, or simply neglect, has led to some deterioration in their conservation value. While the British Government has set a target of achieving favourable conditions (defined as a habitat with a stable or increasing area, key features indicating high quality, no obvious threats to the habitats future and the ability to support a range of typical species now and in the forseable future) for $95 \%$ of SSSIs nationally by 2010 (DETR 2000), in the New Forest the sheer size and complexity of the areas concerned and the number of organisations and individuals involved means that the production and implementation of detailed 
management plans will require considerable resources (New Forest Committee 2003).

In developing plans, the manager is faced with a range of user groups that have different perceptions of the forest and ideas about its management. Sustainability is probably the most important objective but also the most difficult to envisage or execute (for the purposes of this article, sustainability is defined as the maintenance of a system, now and in the future, in such as way that there is no loss or degradation of critical and valued elements of that system). For example, the current dramatic appearance of most A\&O woodlands (Figs. 4, 5) can be considered the result of over 100 years abandonment after a long period of intensive management. Many people would see preserving the present character of A\&O woodland as important (sustaining a valued landscape) while from an ecological perspective these woodlands are part of an evolving landscape that is far from being in a stable, non-changing state. From this longer-term perspective, sustainability must include a regeneration and management cycle that operates over decades to centuries. However, this longer-term approach may significantly alter the current structure and appearance of the $\mathrm{A} \& \mathrm{O}$ woodland, potentially destroying their current aesthetic qualities, though continuing to support or even increase the high biodiversity associated with them.

Within the A\&O woodland beech plays an important role, and it will be focused upon in the following account, because it is potentially the most vulnerable of the key $\mathrm{A} \& \mathrm{O}$ tree species to both current pressures and predicted future changes.

\section{Importance of beech in southern England}

Beech in southern Britain has long been favoured by human activity through the clearance of competing oaks, and

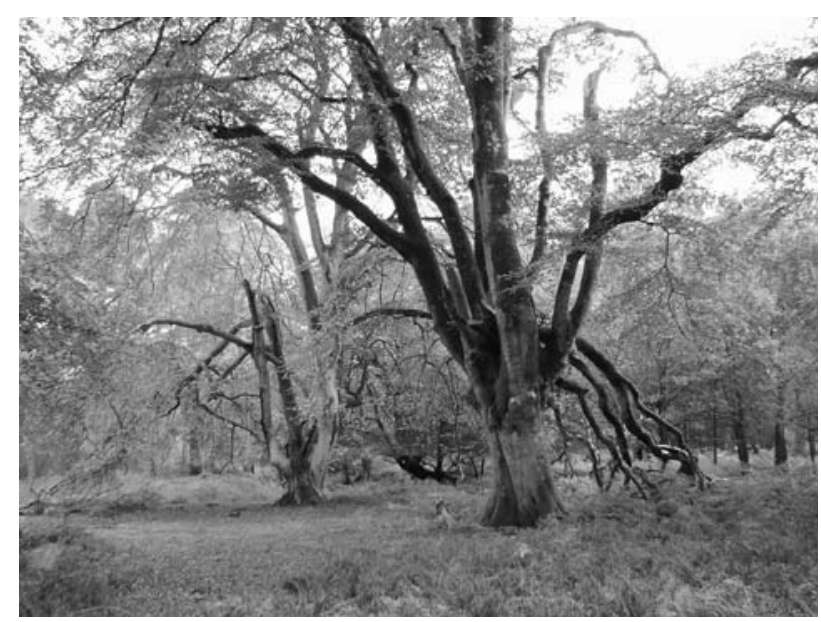

Fig. 4 Beech pollards within Mark Ash Wood

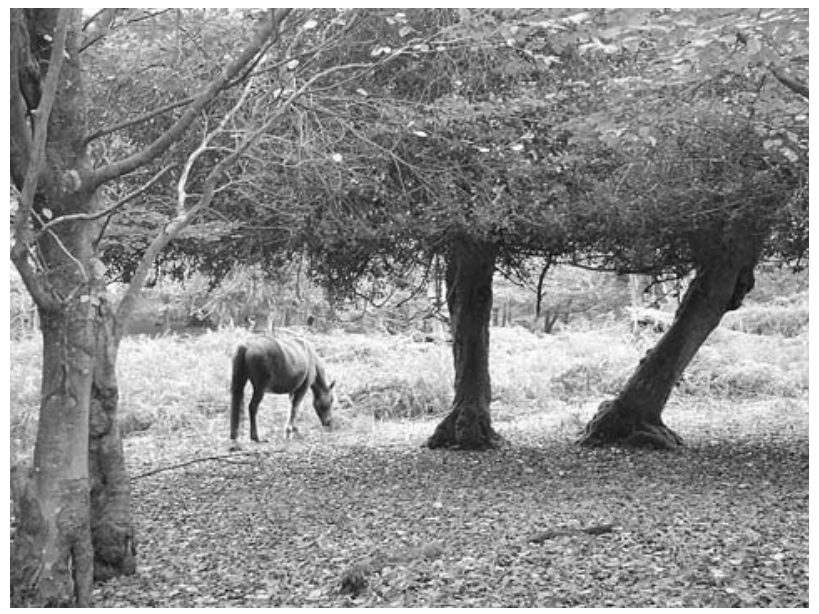

Fig. 5 Grazing within Mark Ash Wood, indicating a clear browse line

through active planting and management for the furniture industry, but a decline in that industry and in active management has resulted in many woods losing beech as a dominant canopy tree (Peterken 1993; Rackham 2003). Beech woodlands are deemed an important component of semi-natural woodland at both a national and European level (e.g. Ratcliffe 1977; EEC 1992). While they exhibit low ground flora species-richness and cover compared with many other woodland types, such as oak, pine plantations and conifer-broadleaf mixtures (Kirby 1988a, b), they also support a high diversity of lichens, fungi and deadwood invertebrates, many of which may be physiologically tied to beech trees themselves (Kirby 2001). Public interest in beech woodlands is also considerable. Beech woods are valued for their recreational, amenity and conservation significance and as defining landscape features in certain localities (Render 2002a, b). They are also prized as living monuments of historical significance, because of their former use for pollarding and coppicing, and association with mediaeval practices such as wood-pasture, fuel and timber production (ERM 2004; Rackham 2003; Rodrick 2001).

The New Forest contains the largest area of mature, semi-natural beech woodland in Britain and represents Atlantic acidophilous beech at the most southerly part of its UK range. More broadly, climatic factors restrict these woodlands largely to the western seaboard of Europe. Atlantic acidophilous beech woodlands are extensive in the Armorican Massif of France and in northern Spain, and there are close associations between the British localities and those found in Brittany and Western Normandy (UKBAP 1994, Annex 1).

Obtaining a long-term perspective on the processes leading to the development of the modern vegetation composition and structure of the $\mathrm{A} \& \mathrm{O}$ woodland is 
important so that informed plans can be developed for its continuation. Palaeoecology and historical data provide information about the past variability of an environment, and they encompass the decadal-to-century timescales over which many ecological processes operate. Modern conservation is often concerned with species that are most at risk, require special protection, or provide an important habitat, but there may be a lack of a thorough understanding of the cultural and palaeoenvironmental conditions that have led to their development. In the absence of this information it is difficult, if not impossible, to predict whether sustainability of a landscape is truly achievable. To understand this long-term development, palaeoecological, historical and long-term monitoring data from $\mathrm{A} \& \mathrm{O}$ woodlands are presented so that an assessment of the modern management schemes can be made.

\section{History of New Forest woodlands: long-term ecological trajectories}

Three dated pollen sequences from valley mire deposits within two A\&O woodlands-Mark Ash Wood and Gritnam Wood-are presented in Figs. 6, 7, 8. The three diagrams demonstrate that Fagus did not become a significant component of the surrounding woodlands until the mediaeval and post mediaeval periods. It is also noticeable that the Fagus expansion is not synchronous. That the Barrow Moor and Church Moor records are from the same area of woodland, only $600 \mathrm{~m}$ apart, suggests that local, small-scale processes were important. Prior to the expansion of Fagus, Quercus and Corylus avellana were the dominant taxa, with Betula also present. At Gritnam Bog Tilia cordata was also present in low

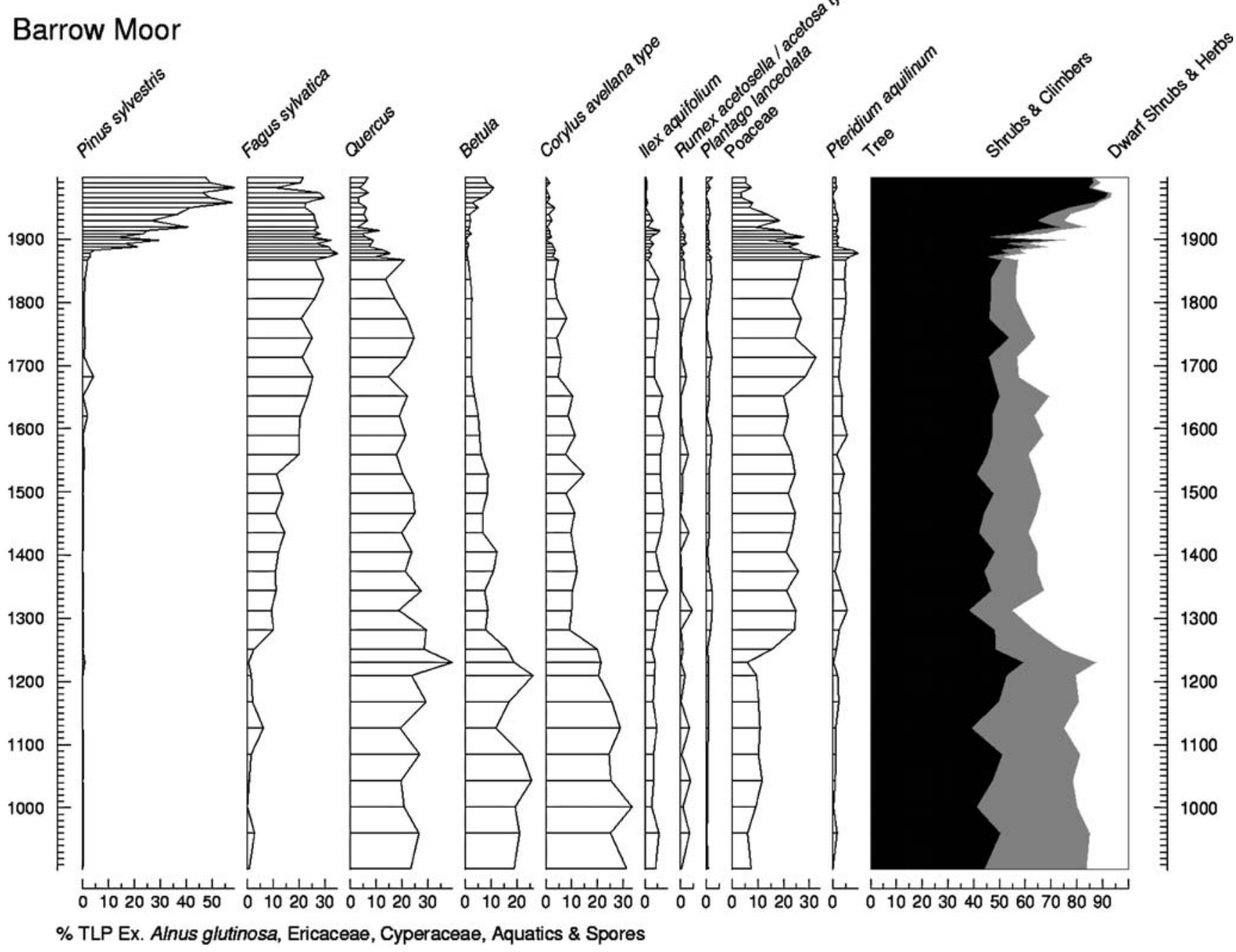

Fig. 6 Summary pollen diagram from Barrow Moor, Mark Ash Wood. Selected taxa are shown. Vertical axis is calibrated calendar years (A.D.) estimated from a linear interpolation between calibrated radiocarbon dates (weighted mean) and age-horizons estimated from Spheroidal Carbonaceous Particle (SCP) concentrations 


\section{Church Moor}

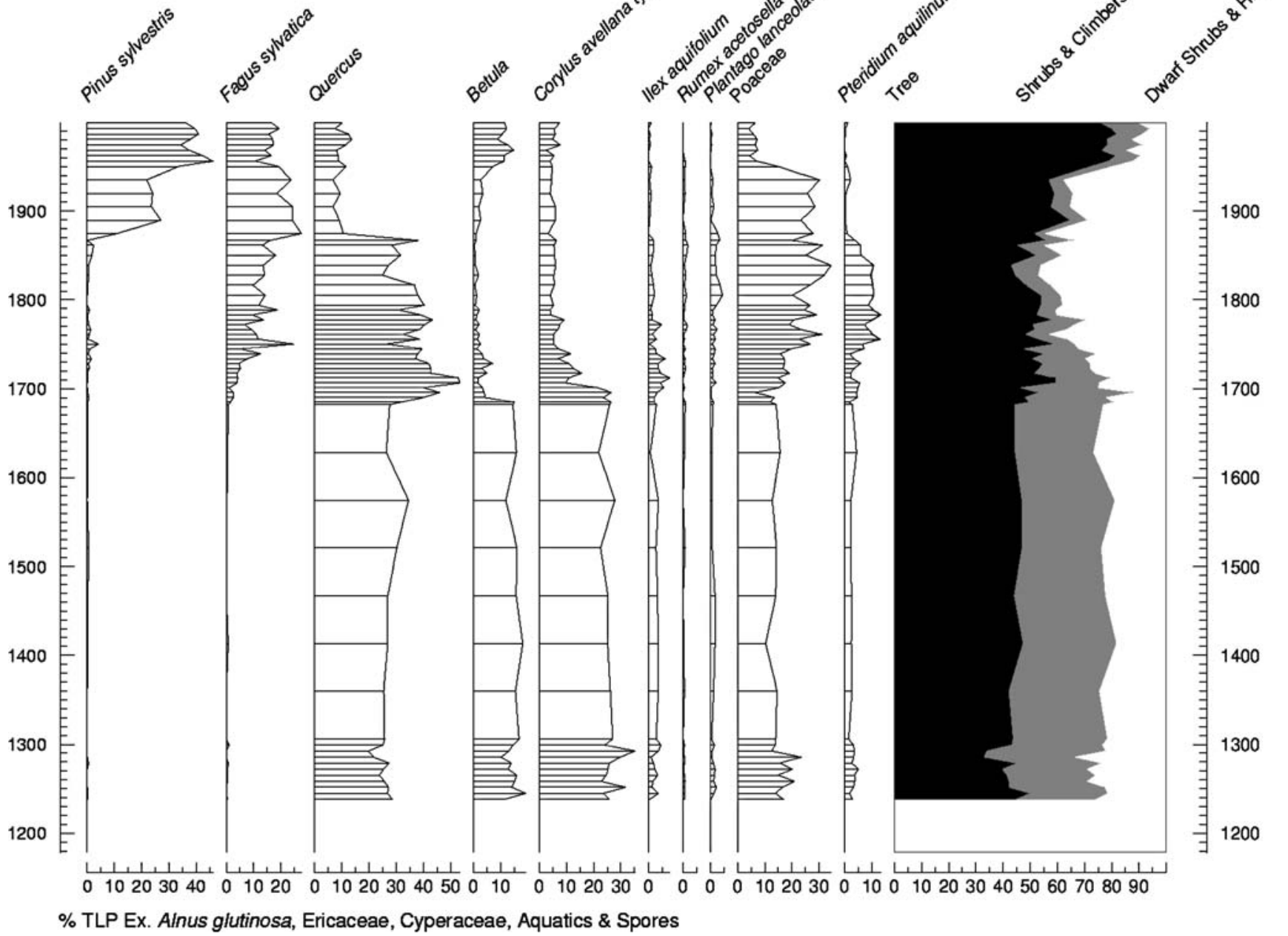

Fig. 7 Summary pollen diagram from Church Moor, Mark Ash Wood. Selected taxa are shown. Vertical axis is calibrated calendar years (A.D.) estimated from a linear interpolation between calibrated

abundance prior to the expansion of Fagus. At each site, the expansion of Fagus coincided with an increase in Ilex aquifolium and herb flora. There were also increases in Plantago lanceolata, Rumex and Pteridium aquilinum, indicative of increased grazing pressure. At Barrow Moor and Church Moor the expansion of Fagus coincided with a notable decline in $C$. avellana. This may be attributed either to the deliberate removal of $C$. avellana to allow Fagus to expand or be planted, abandonment of coppicing and the transfer of the land to wood-pasture, and/or increased grazing pressure. These changes in woodland composition probably reflect the conditions for the development of what would today be thought of as $\mathrm{A} \& \mathrm{O}$ woodland. The increase in Pinus sylvestris represents establishment of local plantations and natural seed regeneration dating from A.D. 1867 onwards. radiocarbon dates (weighted mean) and age-horizons estimated from Spheroidal Carbonaceous Particle (SCP) concentrations

The date for the arrival of Fagus in southern Britain is still unclear, but pollen sequences from Church Moor (Grant 2005) and Wareham (Seagrief 1959) indicate that it was present by $6,000 \mathrm{cal}$ years B.P.. This initial increase is often very low (1-2\%), indicating that Fagus was only a minor woodland component. The main expansion of Fagus values in southern Britain is normally associated with anthropogenic activity, often coinciding with a reduction in Tilia values. In the High Weald area of southern Britain the expansion of Fagus is related to a change in the character of human activity, particularly the adoption of the woodpasture system (Waller and Schofield 2006). Activities such as pannage (feeding by domestic pigs on acorns) may have particularly favoured Fagus as its seeds are highly dependant upon ground disturbance for establishment (Björkman 1999; Watt 1923). Additional activities such as 


\section{Gritnam Bog}

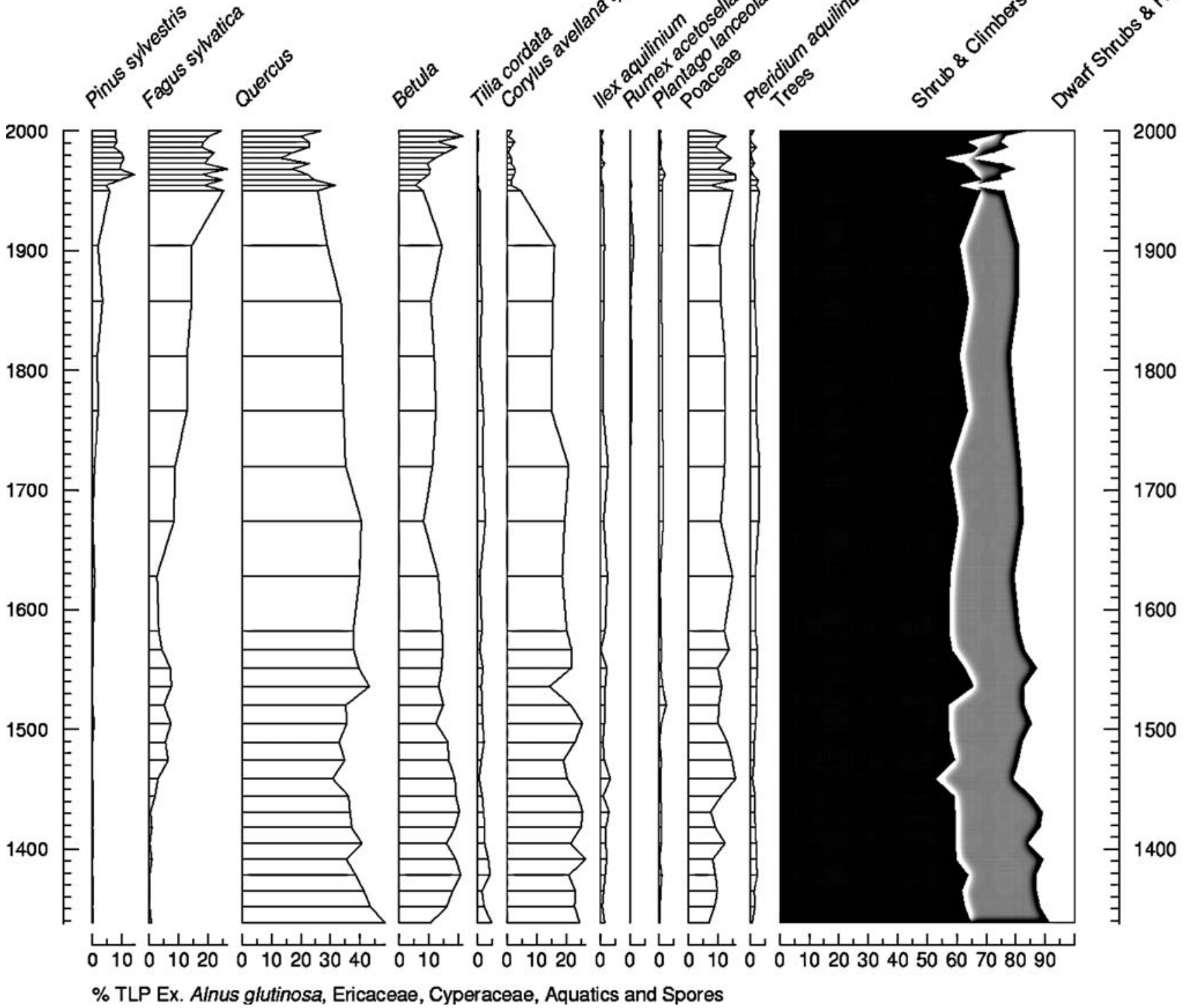

Fig. 8 Summary pollen diagram from Gritnam Bog, Gritnam Wood. Selected taxa are shown. Vertical axis is calibrated calendar years (A.D.) estimated from a linear interpolation between calibrated

the selective removal of Quercus, particularly for naval construction in the New Forest (Flower 1980; Tubbs 2001) and improved drainage over the past 300 years have also assisted the expansion of Fagus.

Implications for long-term management can be drawn from the palaeoecological data. First, current Fagus dominance within the $\mathrm{A} \& \mathrm{O}$ woodlands is a relatively recent development in the landscape. Second, present Fagus dominance has been accomplished by changes in management techniques and grazing activity, and therefore is radiocarbon dates (weighted mean) and age-horizons estimated from Spheroidal Carbonaceous Particle $(S C P)$ concentrations

largely attributable to human intervention rather than natural processes alone.

\section{Processes maintaining $\mathrm{A} \& \mathrm{O}$ woodlands}

Two principal processes have shaped the current A\&O woodland: grazing and traditional tree management (Chatters 1995; Peterken et al. 1996, 1999). The presence of grazing in $\mathrm{A} \& \mathrm{O}$ woods is critical in maintaining their 
open character and structural diversity. Grazing pressure is also intrinsically linked with the regeneration of the trees themselves (Peterken and Tubbs 1965; Flower and Tubbs 1982). Fluctuations in grazing pressure can be recognized in the age structure of the unenclosed woodland, which exhibits three distinct generations, named the $\mathrm{A}, \mathrm{B}$ and $\mathrm{C}$ generations (Peterken and Tubbs 1965). The A generation contains pollards dating from $c$. A.D. 1700. The B generation was established after the A.D. 1851 Deer Removal Act, when deer were almost exterminated from the New Forest. The $\mathrm{C}$ generation marks the most recent regeneration phase when grazing pressure reduced between A.D. 1935 and A.D. 1955 and small enclosures were created to promote growth. During these phases, lower grazing pressure led to an increase in scrub cover, which acted as a nursery for tree regeneration. In addition to these three pulses there has also been a steady, but low, background level of regeneration.

Traditional management includes the pollarding of trees and shrubs. Many of the A generation trees, particularly beech, were formerly pollarded. Pollards are important as they provide important microhabitats and hence niches that are not associated with standard trees, and these foster high diversity in the lichen, fungus and bryophyte communities. However, pollarding has not been commonly practiced within the New Forest for at least 100 years. Holly was also commonly pollarded in the past to provide fodder for grazing animals during the winter months. The 1851 Deer Removal Act resulted in not only a reduction in grazing pressure but also the abandonment of holly cropping as there was no longer any need to feed deer. This subsequently led to an expansion of holly within the shrub layer and canopy woods. Although the holly scrub provides the opportunity for timber regeneration, the heavy shade it creates has proved unsuitable for certain lichen species (Peterken et al. 1999). Recently, the reintroduction of the cutting of holly resulted in both improved light conditions and the provision of winter browse for grazing animals. Timber extraction, when it occurred, was based upon the selection of suitable trees rather than large-scale clearance. This ensured, to a degree, the maintenance of continuous woodland cover, with the openings creating structural diversity, which has probably had some positive effects on the regeneration of some elements of the flora and fauna, but also has allowed beech to become increasingly dominant.

Past changes in land use through the expansion of silvicultural plantations and farmland has led to the isolation of several A\&O woodlands. This has had the effect of increasing dominance by a single generation of trees nearing the end of their lifespan. There is also often an absence of suitable propagules from outside the wood and opportunities for regeneration on the edge of the stand are limited by other land uses (Chatters 1995). Furthermore, oak, one of the A\&O key species, regenerates in well- illuminated conditions on the edge of woods or in extensive glades, thus in isolated stands oak regeneration can be delayed until such time as substantial glades have formed within the woodland site, which is by then perceived to be in a state of decay. Whereas past fluctuations in grazing pressure have traditionally resulted in pulses of tree regeneration (Flower 1980; Flower and Tubbs 1982; Peterken and Tubbs 1965; see above), the current policy of supporting the commoners' gazing economy removes fluctuations in animal numbers related to changes in the market value of livestock. Currently, stocking levels are exceedingly high by historical standards, and they are a contentious management issue (see discussions in Mountford et al. 1999; Peterken et al. 1999; Tubbs 2001).

Amenity use has an impact on high-use areas, particularly around camp sites and car parks. Damage may be in the form of deliberate destruction to young trees or increased trampling leading to soil compaction, which prevents natural regeneration. With the prediction of increased numbers of visitors to the New Forest it may become imperative that recreational facilities are moved away from the most sensitive areas that they currently occupy to reduce this potential damage.

\section{Recent trajectory of an A\&O woodland: 50 years at Denny Wood}

A favoured technique in modern conservation and management practice is to establish long-term monitoring programs. The New Forest A\&O woodlands have been subject to a series of programs lasting up to 50 years. At Denny Wood (monitored since 1956; Manners and Edwards 1986; Mountford et al. 1999; Mountford and Peterken 2003) there has been a general decrease in the extent of the canopy and understory, particularly for beech. Several main causes have been identified. High grazing pressure has resulted in minimal regeneration, although oak has managed some regeneration within inclosures where ponies, but not deer, were excluded. Direct cutting and active removal of some holly trees has also opened up the woodlands. The severe drought of 1976 led to the death and severe weakening of many A-generation beech trees. The storm events of 1987 and 1990 caused further damage, either blowing over the dead and weakened trees, or expanding areas already opened by the drought. Introduced grey squirrels, which expanded greatly in the UK during the 20th century, have played an active role in damaging $\mathrm{C}$ generation beech trees through bark stripping and the removal of bast. These combined impacts have led to an observed canopy collapse within some A\&O woodlands. The death of the A-generation pollards, which occupied a large canopy space, has been instrumental in accelerating 
this decline, and continued high grazing pressure and bracken growth have prevented sufficient regeneration from occurring within the gaps.

\section{Management options}

About 10 years ago, the Forestry Commission solicited input and debate on how to manage unenclosed woodland (including $\mathrm{A} \& \mathrm{O}$ woodlands) and set up an Advisory Committee (Peterken et al. 1996, 1999; Chatters 1995). Three broad options were put forward:

1. Non-intervention;

2. Controlling external factors, such as grazing pressure;

3. Active management including the reintroduction of pollarding.

The resultant management proposals from this consultation largely focused upon the removal of non-native and invasive species, along with bracken control, implementation of some deer exclosures, lopping of young trees to create pollards, and the continuation of monitoring programmes (Peterken et al. 1999).

Measures put into place were not related to arresting the potential decline of beech-dominated $\mathrm{A} \& \mathrm{O}$ woodlands, but instead to the removal of invasive species such as sycamore and rhododendron and prevention of bracken expansion. The pollarding of young beech is an attempt to replace the aging A generation pollards, but the scale over which this has been implemented is limited and will require sustained management over a prolonged time period.

Beech is potentially more susceptible than oak to environmental stresses and to human and biological pressures in the future, which will influence its extent and competitiveness. Grazing pressure may be especially detrimental if it remains artificially high, and damage by squirrels not only hinders growth and weakens the tree, but may also make it more susceptible to fungal attack (Cartwright and Findlay 1946). It must also be remembered that beech is a relatively recent addition as a dominant tree within the New Forest woodlands. Past management has been instrumental in this expansion, and natural processes would probably have not resulted in it becoming a dominant member of the community. As beech is at the limits of its climatic range, factors such as pathogens and competition will play a large role in its ability to remain dominant within the community. In comparison, oak has maintained dominance for many millennia against the background of both natural and anthropogenic pressures and should remain dominant into the near future.

The role of climate change is still often neglected in management plans and the designation of conservation legislation. While recognition of this issue is increasing, it is still unclear as to exactly where future trends will lead and what their subsequent impact upon ecosystems and individual species will be. The recently published Strategy for the New Forest (New Forest Committee 2003) acknowledges that climate change is a potential problem, but it associates this mainly with changes in the coastal zone. An increased dominance of drought-tolerant tree species (such as $P$. sylvestris and Betula spp.) is acknowledged, but the report neglects the possible effects upon taxa already present, such as beech. Existing future climate predictions for southern Britain suggest hotter summers and reduced summer precipitation (IPCC 2001), with model simulations suggesting that storm events may become stronger and more frequent (Wesche 2003). This combination of events is detrimental to beech for the following reasons:

1. Beech has a shallow root system and is therefore vulnerable to drought (as evident in 1976).

2. The shallow root system makes beech prone to treethrow events during storms (as shown in 1987 and 1990).

3. The combination of drought and storm events, as recorded in the Denny Wood monitoring program, leads to increased destruction of beech woodland.

4. The presence of dangerous and dying trees within a landscape used extensively for recreation potentially carries public liability issues, thus requiring further removal of beech trees from areas of $\mathrm{A} \& \mathrm{O}$ woodland.

If this combination of events were to take place, sustaining beech is going to require more intensive human intervention in the form of management. However, nature conservation designations, particularly the Wildlife and Countryside Act and its considerable strengthening under the UK Countryside and Rights of Way Act 2000, and the requirement under the EU HD to maintain habitats in favourable condition, may result in the logistic and financial obligations of maintaining beech becoming increasingly impracticable and uneconomical. In addition, government policy is clearly aimed at preventing further damage to SSSIs and to restore sites to a favourable condition within a specified time frame. A plan or project cannot be sanctioned if it would demonstrably result in a decline in the condition of designated features. Natural England (incorporating English Nature) cannot issue consent for any activity which would cause damage to an SSSI, and public bodies have a statutory duty to further nature conservation in the exercise of their various functions. There is the potential for contradiction if certain traditional woodland management is deemed important for sustaining $\mathrm{A} \& \mathrm{O}$ woodlands over the longer timescale but may result in short-term changes that are deemed undesirable, particularly with regard to the appearance of $\mathrm{A} \& \mathrm{O}$ woodlands 


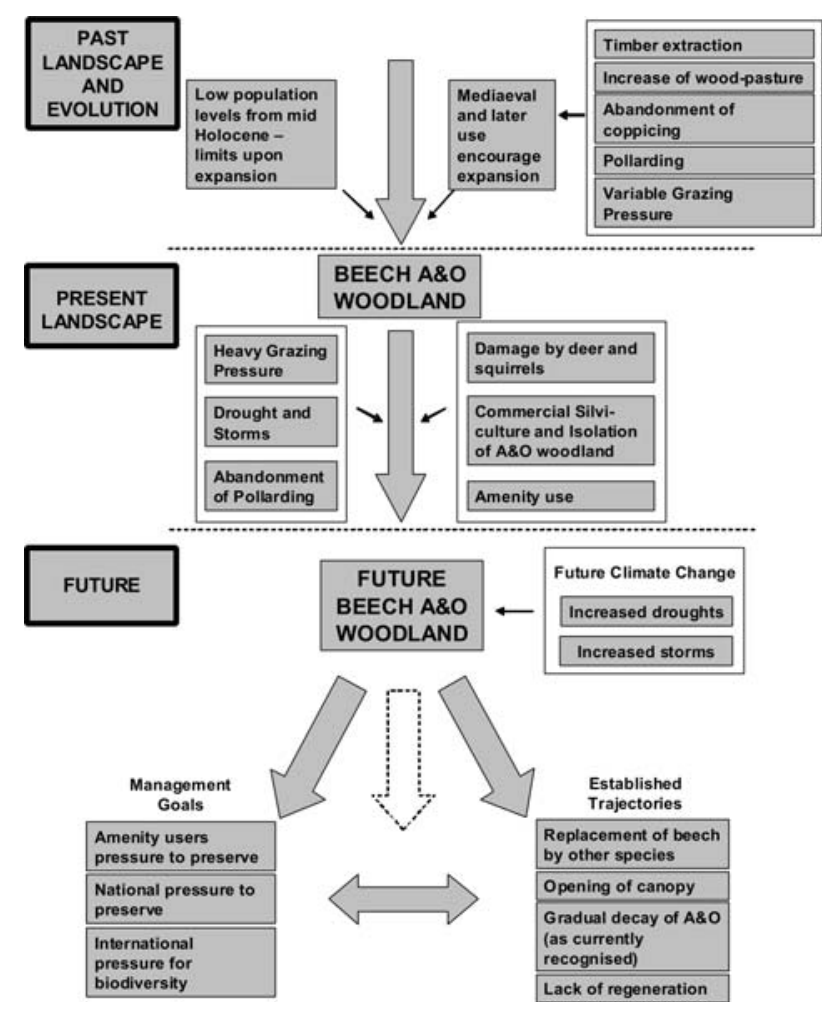

Fig. 9 Past, present and future trajectories of the A\&O system in relation to environmental pressures and management options

and the perceptions of amenity users that these are being harmed.

\section{Discussion}

The intricacies of the natural and human-induced processes that have led to the development of the modern $A \& O$ woodlands make management issues particularly difficult. The palaeoecological record indicates the relative newness of this landscape and suggests that its composition may well be far from what would naturally occur within the New Forest. If a landscape is cultural in origin, to sustain it in its current state normally involves the traditional management practices that formed the landscape as we know it (or substitutes that achieve the same effect). Such practices are used, for example, in the maintenance of chalk downlands in the UK and for northwest European heathlands (e.g. DEFRA 2002; UKBAP 1994; Vandvik et al. 2005; Webb 1998). In the New Forest, human intervention is probably required for any attempt to maintain $\mathrm{A} \& \mathrm{O}$ woodlands in a state similar to that of today.

Management of grazing levels is one issue. If grazing pressure is too high (as at present) regeneration is suppressed, but if it is too low the open character of the woodlands is diminished. Over the past 300 years shifts in economy and management have led to variable grazing pressures through time and the resultant three-generation pattern, which underlies current woodland age and size structures. In the future there is a need to be able to control grazing animal numbers or grazing pressure upon individual units of land. Deer also impose strong pressure on tree regeneration. Closer control of their numbers may provide a more viable and, to some groups, more acceptable management technique. Exclosures can encourage regeneration, but should only be used at a very local scale as they promote single-age regeneration stands. Again, this approach may result in high economic costs and the protection of relatively few trees.

As well as deciding upon actions required to sustain A\&O woodlands based on past trajectories and current conditions, managers also need to look to future changes, particularly climate change, which may have a large impact upon the landscape. Beech is unlikely to fare well in southern England under the expected climate changes of the 21 st century and beyond, and thus management intervention will also be likely to deal with climatically generated pressures. This might take the form of deliberate planting and maintenance of individual beech trees and increased pollarding to reduce the occurrence of tree-throw from increased storm events. Such strategies actually fit well with those required for sustaining the structure and composition of $\mathrm{A} \& \mathrm{O}$ woodland, but are resource-intensive. Even these actions may prove to be an uphill battle as environmental conditions become less favourable to the growth of beech. If current trends continue, especially if resources are not available for fairly intensive beech management, then beech may once again become a minor or isolated component in many $\mathrm{A} \& \mathrm{O}$ woodlands, similar to its status during the mid-Holocene. Even without climate change, the structure of $\mathrm{A} \& \mathrm{O}$ woodlands reflects 300 years of management and incidental use, and their current age structure imparts a future trajectory to stand development, with the inevitable opening up of old stands within the present woodlands prior to any subsequent regeneration. It will now be some time before a new generation of trees matures, no matter what management strategy is adopted. Figure 9 illustrates past, present and future trajectories of the $\mathrm{A} \& \mathrm{O}$ system in relation to environmental pressures and management options.

\section{Conclusions}

Both a long-term perspective on the development of New Forest A\&O woodlands and the expected magnitude of future climate change challenge commonly accepted boundaries for conservation management. Even the concepts 'native species' and 'native range' will lose relevance 
and must be redefined to allow the development of relevant conservation policy (Wesche 2003). The present dominance of ancient beech in these important sites results from an interaction of accidental and more purposeful human activity (and subsequent neglect) and the ecology of beech in the context of the environmental conditions prevailing during the last millennium. As the rate of environmental change increases in the future, management strategies that focus on maintaining key species in habitat-specific conservation areas, even with various forms of intervention, may not be effective. Management of the New Forest landscape, as with many others, will require flexibility, and a broad definition of the woodland ecosystem and of what constitutes resilience (or sustainability) in the face of both changes in human activity/management and climate change. In a region that is important to so many different constituencies it is also critical that public and institutional perceptions are flexible in order that an informed and applicable management strategy can be agreed. In particular, the conflicts over grazing have to be resolved, and the growing numbers of amenity users need to know that the 'idealized' landscape of A\&O wood pastures will inevitably change in the future.

Acknowledgements Part of this research was funded through a Ph.D. scholarship awarded to MJG jointly by the School of Geography, University of Southampton, and the John Lewis Partnership. Radiocarbon dates were provided by NERC and analysed at the NERC Radiocarbon Laboratory, East Kilbride. We thank Prof. Keith Barber, Dr. Alastair Brown, Tim Daley, Dr. Leanne Franklin-Smith, Dr. Paul Hughes, Dr. Paul Combes, Dr. Jenny Schultz and Sue Way for their assistance during fieldwork. We also thank Dr. Jonathan Spencer of the Forestry Commission for allowing access to carry out fieldwork. We thank Prof. Marie-José Gaillard for the invitation to present this paper at the HITE-PolLandCal Conference in Umeå, Sweden, 13-14 November 2005, and the PolLandCal Network, sponsored by NorFA (Nordic Council of Advanced Studies), for providing financial assistance to participate in the conference. Two anonymous referees are thanked for comments and suggestions that led to the improvement of this manuscript.

\section{References}

Björkman L (1999) The establishment of Fagus sylvatica at the standscale in southern Sweden. Holocene 9:237-245

Cartwright K St G, Findlay WPK (1946) Decay of timber and its prevention. HMSO, London

Chatters C (1995) The management of "ancient and ornamental" and other unenclosed woods in the New Forest. Hampshire Wildlife Trust, Eastleigh

DEFRA (2002) Blackdown hills ESA (PB 6989/BH), DEFRA Publications, London

DETR (2000) Our countryside: the future. HMSO, Norwich

Edwards ME (2005) Land-use history in the uplands of Norway and Britain: comparisons, contradictions. In: Thompson DBA, Price MF, Galbraith CA (eds) Mountains of northern Europe: conservation, management, people and nature. Scottish Natural Heritage, Edinburgh, pp 163-178
EEC (1992) Council directive on the conservation of natural habitats and of wild fauna and flora (the habitats and species directive). (92/43/EEC), European Economic Community, Brussels

ERM (2004) http://www.woodland-trust.org.uk/campaigns/images/ qol.pdf. Cited 10 Sept 2005

Forestry Commission (2004) http://www.forestry.gov.uk/pdf/NewForestFacts.pdf/\$FILE/NewForestFacts.pdf Cited 10 Sept 2005

Flower N (1980) The management history and structure of unenclosed woods in the New-Forest, Hampshire. J Biogeogr 7:311-328

Flower N, Tubbs CR (1982) The New Forest, Hampshire. Management proposals for unenclosed woodlands of special importance in the statutory inclosures. NCC, Lyndhurst

Grant MJ (2005) The palaeoecology of human impact in the New Forest. Unpublished Ph.D. Thesis, University of Southampton

IPCC (2001) Climate change 2001: impacts, adaptation, and vulnerability. A report of working group II, intergovernmental panel on climate change. Cambridge University Press, Cambridge

JNCC (2002) Natura 2000 data form. http://www.jncc.gov.uk/protectedsites/SACselection/n2kforms/UK0012557.pdf. Cited 21 Mar 2006

Jones M (1991) The elusive reality of landscape: problems of interpretation. Nor J Geogr 45:229-244

Kirby K (1988a) Changes in the ground flora under plantations on ancient woodland sites. Forestry 61:317-338

Kirby K (1988b) NVC key to woodland and scrub. English Nature, Peterborough

Kirby K (2001) Is beech best? The place of beech in woodland conservation strategies in England. In: Render MG (ed) Goodbye to beech-farewell to Fagus? Transnational Woodland Industries Group Report, Oxford, pp 7-10

Lowenthal D (1999) From landscapes of the future to landscapes of the past. Nor J Geogr 53:139-144

Manners JG, Edwards PJ (1986) Death of old beech trees in the New Forest. Proc H Field Club Archaeol Soc 42:155-156

Mountford EP, Peterken GE (2003) Long-term change and implications for the management of wood pastures: experience over 40 years from Denny Wood, New Forest. Forestry 76:19-43

New Forest Committee (2003) Strategy for the New Forest. New Forest Committee, Lyndhurst

Mountford EP, Peterken GF, Edwards PJ, Manners JG (1999) Longterm change in growth, mortality and regeneration of trees in Denny Wood, an old-growth wood-pasture in the New Forest (UK). Perspect Ecol Evol Syst 2:223-272

Olwig KR (1996) Recovering the substantive nature of landscape. Ann Assoc Am Geogr 86:630-653

Olwig KR (2000) The place ecology of landscape. In: Skärbäck E (eds) Planering för landskap. Stad \& Land 166, Sveriges landbruksuniversitetet, SLU, Alnarp, pp 37-55

Peterken GF (1993) Woodland conservation and management. Chapman \& Hall, London

Peterken GF, Tubbs CR (1965) Woodland regeneration in the New Forest, Hampshire, since 1650. J Appl Ecol 2:159-170

Peterken GF, Spencer JW, Field AB (1996) Maintaining the ancient $\&$ ornamental woodlands of the New Forest. Forestry Commission, Lyndhurst

Peterken GF, Spencer JW, Field AB (1999) Plan for the ancient \& ornamental woodlands of the New Forest. Forestry Commission, Lyndhurst

Rackham O (2003) Ancient woodland. Castlepoint Press, Colvend

Ratcliffe DA (1977) A nature conservation review. Cambridge University Press, Cambridge

Render M (2002a) Wodland management-the owners' views. Q J Forestry 96:143-148

Render M (2002b) Woodland management-the views of the public. Q J Forestry 96:210-216 
Rodrick S (2001) Beech, birch or broadleaves-does it matter? In: Render MG (eds) Goodbye to beech-farewell to Fagus? Transnational Woodland Industries Group Report, Oxford, pp 38-40

Rose F, James PW (1974) Regional studies on the British Lichen Flora. 1. The corticolous and lignicolous species of the New Forest, Hampshire. Lichenologist 6:1-72

Seagrief SC (1959) Pollen diagrams from Southern England: Wareham, Dorset and Nursling. New Phytol 58:316-325

Tubbs CR (2001) The New Forest. New Forest Ninth Centenary Trust, Lyndhurst

UKBAP (1994) Biodiversity: the UK action plan. HMSO, London

UNEP (United Nations Environmental Programme) (1992) Convention on biological diversity. United Nations Environmental Programme, Nairobi, Kenya

Vandvik V, Heegaard E, Måren IE, Aarrestad PA (2005) Managing heterogeneity: the importance of grazing and environmental variation on post-fire succession in heathlands. J Appl Ecol 42:139-149

Waller MP, Schofield JE (2006) Mid to late Holocene vegetation and land use history in the Weald of South-eastern England: multiple pollen profiles from the Rye area. Veget Hist Archaeobot, published online, DOI: 10.1007/s00334-006-0042-1

Watt AS (1923) On the ecology of British beechwoods with special reference to their regeneration. Part I. The cause of failure of natural regeneration of the beech (Fagus silvatica L.) J Ecol $11: 1-48$

Webb NR (1998) The traditional management of European Heathlands. J Appl Ecol 35:987-990

Wesche S (2003) The implications of climate change for the conservation of beech woodlands and associated flora in the UK. English Nature Research Reports 528, English Nature, Peterborough 